\title{
Accommodation of Yeast to Toxic Levels of Cadmium Ions
}

\author{
By IAN G. MACARA* \\ Department of Biochemistry, University of Nairobi, \\ P.O. Box 30197, Nairobi, Kenya
}

(Received 9 August 1977)

Saccharomyces cerevisiae can accommodate to the presence of toxic levels of $\mathrm{Cd}^{2+}$. This adaptation can also be induced, though to a lesser degree, by pre-growth of the yeast in $50 \mu \mathrm{M}-\mathrm{Zn}^{2+}$. Growth of $\mathrm{Cd}^{2+}$-adapted yeast through several passages in $\mathrm{Cd}^{2+}$-free medium leads to a progressive decrease in $\mathrm{Cd}^{2+}$-tolerance by the yeast, suggesting that the adaptation did not involve selection of a $\mathrm{Cd}^{2+}$-resistant mutant. Chromatography on Sephadex G-75 of the soluble fraction from $\mathrm{Cd}^{2+}$-adapted yeast indicated that no metallothionein-like protein was present. This suggests that the mechanism of adaptation is unlike that of the higher eukaryotes.

\section{INTRODUCTION}

The toxicity of cadmium is well documented and numerous studies of its biochemical effects have been made (for review, see Vallee \& Ulmer, 1972). An adaptive response to $\mathrm{Cd}^{2+}$, that protects the organism against damage by the cation, has been observed both in human tissue (Rugstad \& Norseth, 1975) and in Escherichia coli (Mitra et al., 1975). The mechanisms of adaptation differ, however. In mammals a cadmium-binding protein, metallothionein, is induced; it can bind 7 to $8 \mathrm{Cd}^{2+}$ or $\mathrm{Zn}^{2+}$ ions and has a molecular weight of about 10000 (Kägi \& Vallee, 1961). In E. coli no metallothionein exists and accommodation appears to involve an inhibition of $\mathrm{Cd}^{2+}$ uptake. Pre-treatment with $\mathrm{Zn}^{2+}$ also elicits the adaptive response, both in $E$. coli and in the rat (Webb, 1972).

The purpose of the present study was to ascertain whether induction of metallothionein represents a general eukaryotic mechanism of accommodation or is restricted to the higher eukaryotes. Failla \& Weinberg (1977) have suggested that a metallothionein-like protein might control $\mathrm{Zn}^{2+}$ accumulation in yeast.

\section{METHODS}

Organism. A strain of Saccharomyces cerevisiae isolated in this laboratory was used. It was grown in

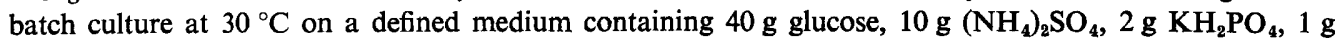
$\mathrm{MgSO}_{4} .7 \mathrm{H}_{2} \mathrm{O}, 0 \cdot 2 \mathrm{~g} \mathrm{NaCl}_{2}, 0 \cdot 2 \mathrm{~g} \mathrm{CaCl}_{2}, 30 \mathrm{mg}$ inositol, $8 \mathrm{mg}$ thiamin, $1 \mathrm{mg}$ pyridoxine, $1 \mathrm{mg}$ calcium pantothenate, $0.5 \mathrm{mg}$ riboflavin, $50 \mu \mathrm{g}$ biotin, $1 \mathrm{mg} \mathrm{H} \mathrm{BO}_{3}, 0.8 \mathrm{mg} \mathrm{ZnSO}_{4} .7 \mathrm{H}_{2} \mathrm{O}$ and $0.6 \mathrm{mg}\left(\mathrm{NH}_{4}\right)_{2} \mathrm{SO}_{4} . \mathrm{FeSO}_{4}$. $6 \mathrm{H}_{2} \mathrm{O}$ in 11 glass-distilled water. Cell concentrations were determined from turbidities measured at $590 \mathrm{~nm}$.

Effect of $\mathrm{Cd}^{2+}$ on growth. The yeast was grown on defined medium alone, or in the presence of either 50 $\mu \mathrm{M}-\mathrm{Zn}^{2+}$ or $50 \mu \mathrm{M}-\mathrm{Cd}^{2+}$, to a concentration of $0.5 \%$ (w/v, wet weight). Samples were then inoculated into fresh medium containing $\mathrm{Cd}^{2+}(0$ to $1 \mathrm{mM})$ to a concentration of $0.01 \%(\mathrm{w} / \mathrm{v})$, and incubated with shaking at $30^{\circ} \mathrm{C}$. Turbidities were measured over a period of $24 \mathrm{~h}$.

In a second experiment, yeast was grown in batch culture through three passages, the concentration of $\mathrm{Cd}^{2+}$ in the medium being doubled at each passage, from 5 to $40 \mu \mathrm{M}$. The yeast was then taken through

* Present address: New England Aquarium Corp., Central Wharf, Boston, Massachusetts 02110, U.S.A. 


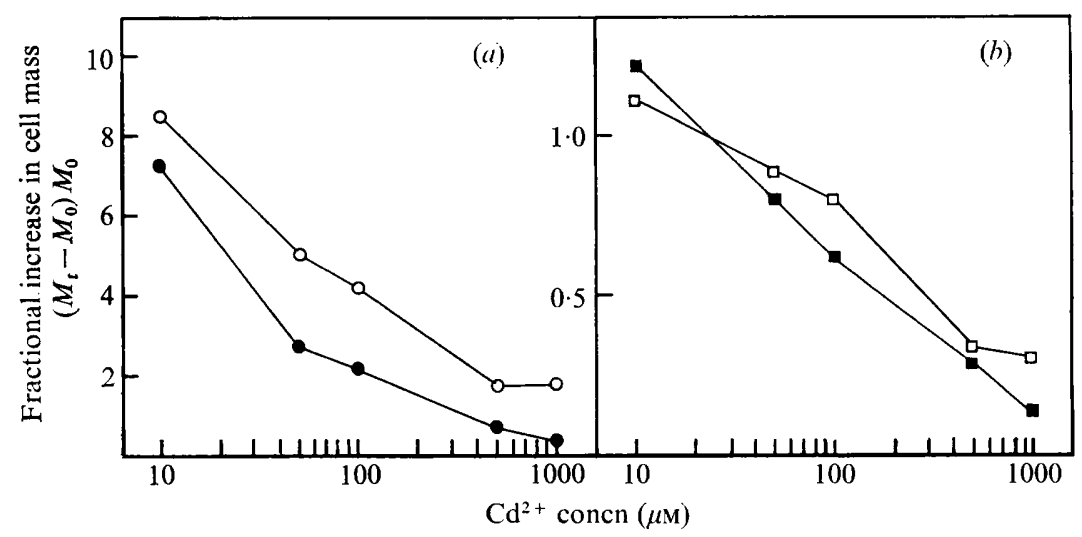

Fig. 1. Effect of pre-growth in $50 \mu \mathrm{M}-\mathrm{Cd}^{2+}(\bigcirc)$ or $50 \mu \mathrm{M}-\mathrm{Zn}^{2+}(\square)$ on the growth of yeast in batch culture on defined medium containing $\mathrm{Cd}^{2+}$, as compared with the growth of normal yeast $(\bullet$, D). Wet weights were calculated from turbidities measured at $590 \mathrm{~nm}$. (a) Growth yield after $24 \mathrm{~h}$, (b) yield after $9 \mathrm{~h}$; yields are expressed as fractional increases in cell mass, $\left(M_{t}-M_{0}\right) / M_{0}$, where $M_{t}$ is the mass (wet wt) at time $t$ and $M_{0}$ the initial mass.

five passages in cadmium-free medium; at each passage a sample was removed and its growth was followed in medium containing $80 \mu \mathrm{M}-\mathrm{Cd}^{2+}$.

Assay of $\mathrm{K}^{+}$release. $\mathrm{K}^{+}$-loaded yeast was grown in medium enriched with $0 \cdot 25 \mathrm{M}-\mathrm{KCl}$. After being washed three times with distilled water, it was suspended to a concentration of $10 \%(\mathrm{w} / \mathrm{v})$ in aqueous solutions of $\mathrm{CdCl}_{2}(0$ to $75 \mathrm{mM})$ or in $7.5 \mathrm{mM}-\mathrm{HgCl}_{2}$. After incubation for $1 \mathrm{~h}$, the yeast suspension was centrifuged and $\mathrm{K}^{+}$in the supernatant was determined by flame photometry at $767 \mathrm{~nm} . \mathrm{K}^{+}$was also determined in the supernatant from a suspension in $2 \mathrm{M}-\mathrm{HCl}$ that had been autoclaved for $20 \mathrm{~min}$ at $121^{\circ} \mathrm{C}$.

Assay of $\mathrm{Cd}^{2+}$ exchange. ${ }^{100} \mathrm{Cd}-$ loaded yeast was prepared by culture in medium containing $5 \mu \mathrm{M}-\mathrm{CdCl}_{2}$, $0.01 \mu \mathrm{Ci} \mathrm{ml}{ }^{-1}$ (carrier-free ${ }^{109} \mathrm{CdCl}_{2}$ from The Radiochemical Centre, Amersham). It was washed with distilled water, followed by $5 \mathrm{~mm}-\mathrm{CdCl}_{2}$, and then suspended to a concentration of $5 \%(\mathrm{w} / \mathrm{v})$ in $50 \mathrm{mM}-$ $N$-tris(hydroxymethyl)methyl-2-aminoethane sulphonic acid, $\mathrm{pH} 6 \cdot 5$, containing $5 \mathrm{mM}-\mathrm{CdCl}_{2}$ and $50 \mathrm{~mm}$ glucose. Samples were removed at intervals up to $60 \mathrm{~min}$, filtered through Millipore filters (pore size 0.45 $\mu \mathrm{m}$ ) and the filtrates were counted using a Packard liquid scintillation spectrometer (Tri-Carb model 3320).

Gel filtration. Sphaeroplasts were prepared from washed ${ }^{109} \mathrm{Cd}$-loaded yeast by the method of Cabib (1971) using crude $\beta$-glucuronidase (Sigma), and disrupted by sonication for $1 \mathrm{~min}$ at $50 \mathrm{~W}$ (Sonifier Cell Disruptor, model W185, Heat Systems-Ultrasonics, U.S.A.). Cell debris was removed by centrifugation at $5000 \mathrm{~g}$ for $10 \mathrm{~min}$ followed by centrifugation at $100000 \mathrm{~g}$ for $1 \mathrm{~h}$. The supernatant was passed through a $70 \times 1.5 \mathrm{~cm}$ column of Sephadex G-75 using 0.001 M-Tris/HCl, pH 8.6, as eluting buffer (Rugstad \& Norseth, 1975).

\section{RESULTS}

Effect of $\mathrm{Zn}^{2+}$ and $\mathrm{Cd}^{2+}$ pre-treatment on growth in $\mathrm{Cd}^{2+}$-containing medium. Cell yields after $24 \mathrm{~h}$ growth in $\mathrm{Cd}^{2+}$-containing medium are shown in Fig. 1(a) for both normal yeast and yeast pre-grown in the presence of $50 \mu \mathrm{M}-\mathrm{Cd}^{2+}$. Initial growth rates were slower for cadmium-adapted yeast at concentrations up to $500 \mu \mathrm{M}-\mathrm{Cd}^{2+}$, but whereas control growth began to decrease after about $8 \mathrm{~h}$, that of the cadmium-adapted yeast continued in exponential phase beyond $24 \mathrm{~h}$. A similar, but less pronounced effect on cell yield was observed for yeast pre-grown in $50 \mu \mathrm{M}-\mathrm{Zn}^{2+}$ (Fig. $1 b$ ).

The ability of cadmium-adapted yeast to grow in medium containing $80 \mu \mathrm{M}-\mathrm{Cd}^{2+} \mathrm{de}-$ creased after subsequent growth in cadmium-free medium (Fig. 2). The degree to which this ability was lost was related to the number of passages of the yeast through the cadmiumfree medium.

Exchange of ${ }^{109} \mathrm{Cd}^{2+}$. Over a period of $1 \mathrm{~h}$ no increase in ${ }^{109} \mathrm{Cd}$ was detected in the filtrates from suspensions of ${ }^{109} \mathrm{Cd}$-loaded yeast in $5 \mathrm{mM}-\mathrm{CdCl}_{2}$.

Effect of $\mathrm{Cd}^{2+}$ on membrane integrity. $\mathrm{Hg}^{2+}$ and $\mathrm{Cu}^{2+}$ damage cell membranes irreversibly (Passow \& Rothstein, 1960). Because of similarities in the chemistry of $\mathbf{H g}^{2+}$ and $\mathrm{Cd}^{2+}$, 


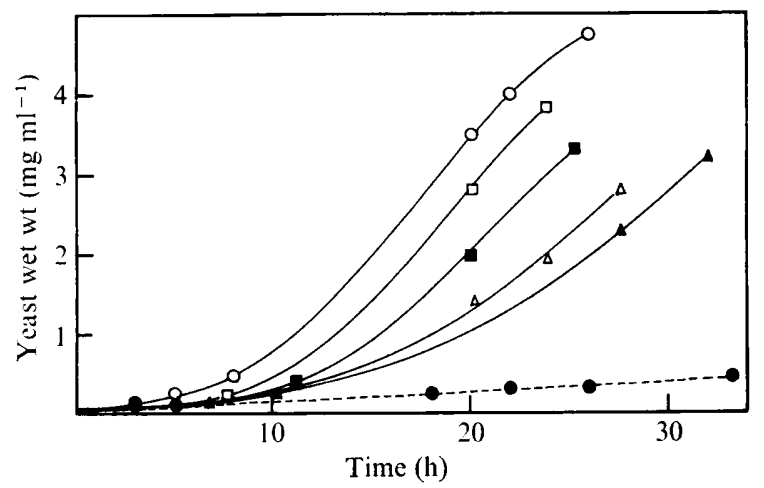

Fig. 2. De-adaptation of yeast towards $\mathrm{Cd}^{2+}$ toxicity. Cadmium-adapted yeast was prepared by growth in batch culture through three passages, the concentration of $\mathrm{Cd}^{2+}$ in the medium being doubled at each passage, from 5 to $40 \mu \mathrm{m}$. This yeast was then grown through five passages on $100 \mathrm{ml}$ cadmium-free medium. Growth of yeast removed at each passage was followed in medium containing $80 \mu \mathrm{M}-\mathrm{Cd}^{2+}$ (from an initial concentration of $0.025 \%$, w/v). Growth of: unadapted yeast on $80 \mu \mathrm{M}-\mathrm{Cd}^{2+}(\odot)$; adapted yeast $(\bigcirc)$; de-adapting yeast, second $(\square)$, third $(\square)$, fourth $(\triangle)$ and fifth $(\mathbf{\Lambda})$ passages.

the effect of $\mathrm{Cd}^{2+}$ on membrane integrity was determined, $\mathrm{K}^{+}$release being used as a criterion of membrane damage. Small amounts of $\mathrm{K}^{+}$(about $5 \%$ of the total $\mathrm{K}^{+}$) were detected in every supernatant in which $\mathrm{Cd}^{2+}$ was present but the amount was independent of $\mathrm{Cd}^{2+}$ concentration over the range 5 to $75 \mathrm{~mm}$. In contrast, $7.5 \mathrm{mM}-\mathrm{Hg}^{2+}$ caused release of all the intracellular $\mathrm{K}^{+}$.

Gel filtration of soluble fraction from ${ }^{109} \mathrm{Cd}$-loaded yeast. After treatment of ${ }^{109} \mathrm{Cd}$-loaded yeast with $\beta$-glucuronidase, about $75 \%$ of the total radioactivity was found in the supernatant. After disruption of the sphaeroplasts and centrifugation, the soluble fraction contained only $9 \%$ of the total radioactivity. Gel filtration of the soluble fraction indicated that about $70 \%$ of the ${ }^{109} \mathrm{Cd}$ was bound to proteins eluted with the void volume (molecular weight $>70000$ ). Most of the remaining ${ }^{109} \mathrm{Cd}$ eluted at $V_{t}$ (total volume) suggesting that it is present as the free ion or bound to substances of low molecular weight $(<3000)$. No ${ }^{109} \mathrm{Cd}$ was detected at an elution volume coincident with that expected for a metallothionein of molecular weight 10000 .

\section{DISCUSSION}

The results suggest that $S$. cerevisiae is similar to both mammals and bacteria in being able to accommodate to the presence of toxic levels of $\mathrm{Cd}^{2+}$, and that this accommodation can also be induced by $\mathrm{Zn}^{2+}$. It is unlikely that the observed resistance is caused by selection of cadmium-resistant mutants since growth in $\mathrm{Zn}^{2+}$-containing-medium exerts no selective pressure at the $\mathrm{Zn}^{2+}$ concentrations used. Moreover, cadmium-adapted yeast shows a progressive de-adaptation when grown in medium lacking $\mathrm{Cd}^{2+}$. This is possibly a reflexion of the progressive dilution of intracellular $\mathrm{Cd}^{2+}$ that must occur during growth. The $\mathrm{Cd}^{2+}$ does not appear to exert its toxic effects by disruption of the yeast plasma membrane.

The absence of an inducible metallothionein suggests that the mechanism of accommodation in yeast may resemble that in $E$. coli. The observation that only $9 \%$ of the ${ }^{109} \mathrm{Cd}$ was found in the soluble fraction of yeast compares closely with the value of $10 \%$ found for $E$. coli by Mitra et al., (1975). In rat liver, $85 \%$ of ${ }^{109} \mathrm{Cd}$ is bound to metallothionein (Winge \& Rajagopalan, 1972).

In several other systems the size of the intracellular pool of a particular metabolite has been shown to regulate the associated transport system by transinhibition (Grabeel \& Grenson, 1970; Cummins \& Mitchison, 1967), and it is possible that high intracellular levels of $\mathrm{Cd}^{2+}$ inhibit the divalent cation transport system in yeast. The observation that 
the degree of de-adaptation is related to the period of growth in cadmium-free medium supports this hypothesis. The kinetics of $\mathrm{Cd}^{2+}$ transport in cadmium-adapted and normal yeasts are being investigated. Since no exchange of ${ }^{109} \mathrm{Cd}$ appears to occur it is unlikely that accommodation involves efflux of the cation.

The absence of a metallothionein in $S$. cerevisiae argues against the suggestion of Failla \& Weinberg (1977) that a protein of this type is involved in control of $\mathrm{Zn}^{2+}$ accumulation by yeasts.

\section{REFERENCES}

CABIB, E. (1971). Isolation of yeast spheroplasts. Methods in Enzymology 22, 120-122.

Cummins, J. E. \& Mitchison, J. M. (1967). Adenine uptake and pool formation in the fission yeast Schizosaccharomyces pombe. Biochimica et biophysica acta 136, 108-120.

Failla, M. L. \& Weinberg, E. D. (1977). Cyclic accumulation of zinc by Candida utilis during growth in batch culture. Journal of General Microbiology 99, 85-97.

Grabeel, M. \& Grenson, M. (1970). Regulation of histidine uptake by specific feedback inhibition of two histidine permeases in Saccharomyces cerevisiae. European Journal of Biochemistry 14, 197-204.

KÄGI, J. H. R. \& VAlleE, B. L. (1961). Metallothionein: a cadmium and zinc-containing protein from equine renal cortex. Journal of Biological Chemistry 236, 2435-2442.

Mitra, R. S., Gray, R. H., Chin, B. \& Bernstein, I. A. (1975). Molecular mechanisms of accommo- dation in Escherichia coli to toxic levels of cadmium ion. Journal of Bacteriology 121, 1180-1188.

Passow, H. \& Rothstein, A. (1960). The binding of $\mathrm{Hg}^{2+}$ by the yeast cell in relation to changes in permeability. Journal of General Physiology 43, 621-633.

Rugstad, H. E. \& Norseth, T. (1975). $\mathrm{Cd}^{2+}$ resistance and content of $\mathrm{Cd}^{2+}$-binding protein in cultured human cells. Nature, London 257, 136-137.

VAllee, B. L. \& Ulmer, D. D. (1972). Biochemical effects of mercury, cadmium and lead. Annual Review of Biochemistry 41, 91-128.

WeBB, M. (1972). Protection by $\mathrm{Zn}^{2+}$ against $\mathrm{Cd}^{2+}$ toxicity. Biochemical Pharmacology 21, 27672771.

Winge, D. R. \& Rajagopalan, K. V. (1972). Purification and some properties of cadmiumbinding protein from rat liver. Archives of Biochemistry and Biophysics 153, 755-762. 